\title{
Tree Vitality and Forest Health: Can Tree-Ring Stable Isotopes Be Used as Indicators?
}

\author{
Paolo Cherubini ${ }^{1,2}$ (D) Giovanna Battipaglia ${ }^{3}$ John L. Innes ${ }^{4}$
}

Accepted: 3 February 2021 / Published online: 27 February 2021

(C) The Author(s) 2021

\begin{abstract}
Purpose of Review Society is concerned about the long-term condition of the forests. Although a clear definition of forest health is still missing, to evaluate forest health, monitoring efforts in the past 40 years have concentrated on the assessment of tree vitality, trying to estimate tree photosynthesis rates and productivity. Used in monitoring forest decline in Central Europe since the 1980s, crown foliage transparency has been commonly believed to be the best indicator of tree condition in relation to air pollution, although annual variations appear more closely related to water stress. Although crown transparency is not a good indicator of tree photosynthesis rates, defoliation is still one of the most used indicators of tree vitality. Tree rings have been often used as indicators of past productivity. However, long-term tree growth trends are difficult to interpret because of sampling bias, and ring width patterns do not provide any information about tree physiological processes.

Recent Findings In the past two decades, tree-ring stable isotopes have been used not only to reconstruct the impact of past climatic events, such as drought, but also in the study of forest decline induced by air pollution episodes, and other natural disturbances and environmental stress, such as pest outbreaks and wildfires. They have proven to be useful tools for understanding physiological processes and tree response to such stress factors.

Summary Tree-ring stable isotopes integrate crown transpiration rates and photosynthesis rates and may enhance our understanding of tree vitality. They are promising indicators of tree vitality. We call for the use of tree-ring stable isotopes in future monitoring programmes.
\end{abstract}

Keywords Dendroecology $\cdot$ Forest health $\cdot$ Forest decline $\cdot$ Tree vitality $\cdot$ Tree rings $\cdot$ Stable isotopes

This article is part of the Topical Collection on Physiological Processes

Paolo Cherubini

paolo.cherubini@wsl.ch

Giovanna Battipaglia

giovanna.battipaglia@unicampania.it

John L. Innes

john.innes@ubc.ca

1 WSL, Swiss Federal Institute for Forest, Snow and Landscape, Zürcherstrasse 111, CH-8903 Birmensdorf, Switzerland

2 Department of Forest and Conservation Sciences, Faculty of Forestry, University of British Columbia, Vancouver, BC V6T 1Z4, Canada

3 Department of Environmental, Biological and Pharmaceutical Sciences and Technologies, University of Campania "L. Vanvitelli", Via Vivaldi 43, I-81100 Caserta, Italy

4 Departme nt of Forest Resources Management, Faculty of Forestry, University of British Columbia, Vancouver, BC V6T 1Z4, Canada

\section{Introduction}

\section{Scientific Hypothesis and Rationale}

Despite the efforts to monitor forest health that have been ongoing for almost 50 years, there is still no clear and universally agreed concept of the vitality of individual trees or the broader concept of forest health. The reason for this lack of definition is the poor understanding of the physiological mechanisms underlying tree mortality and forest dieback episodes. Recently, there has been some level of agreement that tree mortality processes involve the storage and transport systems of water and photosynthate. Extreme drought events induce runaway xylem embolism and eventually the loss of xylem hydraulic conductivity, causing tree death.

Stable isotope analysis of tree rings provides a powerful method to assess physiological processes in trees retrospectively and to understand the role played by drought in forest decline episodes. We postulate that the recent forest dieback 
episodes that have been observed were induced by drought. We further propose that some of the episodes of mortality and dieback observed during the 1970s and 1980s were also caused by drought. If this is the case, then stable isotopes, which integrate information about stomatal activity and photosynthesis, should be a much better indicator of tree vitality than more commonly used indicators such as tree-ring width and crown transparency.

\section{Forest Health}

Forests are important to society because they provide multiple goods and services, including the maintenance of biodiversity, production of timber, protection against natural hazards, and provision of cultural and recreational benefits. Poor forest health is associated with the loss of some of these goods and services. As a result, society is increasingly concerned about the long-term condition of the forests. Questions about the state of the forests often arise when and where there are no other major upheavals and woes, such as wars, famines, waves of poverty, or pandemics. The importance of healthy forests typically becomes a topic of discussion when natural hazards such as wildfires, avalanches, and landslides occur, or when dramatic forest declines are observed. In such cases, it becomes clear how important it is to be able to assess forest health, as well as how deep our ignorance is of baseline conditions.

Scientists, when asked about the state of the forests, often provide controversial answers, evidence that a clear consensual definition of forest health is still missing. When forest declines occur, forest health becomes a matter of public debate and political discussion, with news cycles strongly influencing public opinion. Depending on what else is in the headlines, small events may garner much attention, whereas larger, more diffuse events may occur without even a passing mention. As a result, many people lack not only a baseline understanding of forest health but also the ability to gauge the relative severity of any particular event. A lack of knowledge tends to make people more inclined to trust "experts", particularly those who offer reassuring theories.

Waldsterben, the forest decline that occurred in Central Europe during the last century, is a good example of sudden, uninformed public interest in forest health. In the 1970s, a decline in silver fir (Abies alba Mill.) stands was observed in Germany, the so-called Tannensterben or fir dieback [1]. Some of the declines were localised around point sources of air pollution, such as in the Black Triangle, i.e., at the borders between Germany, the Czech Republic, and Poland, and were evidently caused by local emissions of pollutants [2]. Later, when a more diffuse and widespread decline of other tree species was observed in European forests (called Waldsterben or forest dieback [3]), mass media jumped on the news and provoked significant alarm. To this day, the cause of the decline remains unclear [4], although droughts seem to have at least triggered some of the declines in health. In Central Europe, particularly in German-speaking countries where forests are considered a symbolic part of the cultural identity [5], citizens were shocked and in some cases there was even panic, incited by environmentalist movements supported by poor or nonexistent science. Governments were induced to adopt measures to reduce pollution emissions and to invest public money in forest health research and monitoring programmes. Questions about the causes of the decline have never really been resolved and remain controversial [6], although it is notable that the symptoms that were observed in the late 1970s (foliage reductions and discoloration) after the severe drought of 1976 were again repeated following droughts in the 1990s and 2000s [7]. Nonetheless, emissions, particularly of sulfurs and heavy metals, dropped significantly over the past 30 years as a result of the Waldsterben fear. At the same time, air quality improved, as did our understanding of forest ecology and ecosystem processes. Ongoing research associated with the ensuing monitoring efforts has shown how complex ecosystem processes are [8] and how difficult it is to define forest health, which we need to do if we want to be able to assess it [9].

Defining forest health is as difficult as defining the health of human populations. What indicators should be used to assess the health of a forest stand? Amongst the different possible indicators, which are most meaningful? Is it the mean, or perhaps the median, tree life expectancy? And, if it is, how can we know how life expectancy compares to life expectancy in the past? How should we assess the health of trees that are attacked by non-lethal fungal pathologies and other diseases and pests? And what mortality rates characterize a healthy forest versus a declining one? It is evident that in order to answer all these questions, a definition of forest health is necessary. However, as noted 15 years ago [10], a clear definition of forest health has been lacking. Our literature search showed that the development of a concept of forest health has been completely neglected for the past twenty years; indeed, no notable advances have been made at all in this regard. Studies of forest health have been limited to the assessment of the condition of single forest stands, mainly those declining as a result of drought [11]. And again, a considered communication between science and society has been lacking. Announcements of global forest health decline have appeared in scientific journals and been broadcast by mass media, causing significant public concern. However, a meaningful definition of forest health is still missing, making it difficult for anyone, expert or lay, to gauge the relative severity of the reported declines and respond accordingly.

Although it may be questioned whether a universal definition of forest health is even possible, it seems unreasonable to base this only on the observations of the appearance of trees. This is a legacy of the past emphasis on production forestry, 
where unhealthy trees were seen as a potential loss of stand yield. Today, with multi-objective forestry, the presence of dead and dying trees is seen as an essential part of the maintenance of biodiversity. Trees and forest stands are only a part of the much larger ecosystem, and their interactions with the other components of the ecosystem have to be considered. In Central European forest ecosystems, for example, forest condition is influenced by soil acidification, extreme climatic events such as drought or frost, pest outbreaks, interactions between primary, secondary, and saprophytic fungal diseases, and many other factors. The complex synergies amongst all these factors determine tree death and forest stand dieback. This is why atmospheric, soil, and hydrological processes should all be taken into consideration when assessing forest health $[12,13]$. However, a distinction between the various factors leading to forest decline is seldom made in the public discourse $[14,15 \cdot]$. Once again, the discussion is misleading and public opinion confounded.

\section{Tree Health, Condition, and Vitality}

Tree vitality is one of the most important indicators of forest condition. Tree vitality, or tree condition, describes the general outer appearance of an individual tree. In contrast, tree health reflects the pathological state of a tree [9]. As vitality cannot be measured directly, various indicators can be used to describe it. If tree vitality is used as an indicator of forest condition during forest surveys, it is clear that field-practical, low-cost methods are needed. Although vitality is a theoretical concept and defined differently in a range of studies, it always includes the power to live, grow, and develop [10]. Therefore, indicators of tree life, growth, and development have to be used. Here, we review the literature dealing with indicators of tree health, together with their main advantages and limitations.

\section{Indicators for Assessing Tree and Forest Vitality}

\section{Tree Death and Mortality Rates}

Like all living organisms, trees die. Tree death is the ultimate indicator of zero tree vitality. Because the definition of tree vitality includes the capacity of a tree to live, one good indicator of tree vitality is tree survival after stress. Predisposing, inciting, and contributing stress factors lead to tree decline. During or after stress, the tree reacts immediately, then usually recovers. Trees usually reallocate carbon to overcome stress; if stress continues, the ability of a tree to overcome stress diminishes until tree death occurs.

However, at what point is a tree actually dead, and how does one know? As with humans, it can be difficult to define a clear border between life and death for trees. For example, is a tree dead as soon as it is felled, even if the crown foliage is still green and actively photosynthesising? Many trees can be grown from cuttings, so clearly a shoot can survive been excised from a tree, at least for a short time. Are cambial cells dead if they are still being fed carbohydrates by the foliage? Or is a stump dead if it is still growing thanks to carbohydrates provided by neighbouring trees through root anastomoses? The stumps of many broad-leaved trees can resprout, so clearly they are not dead. Our understanding of tree-longevity mechanisms [16] and prior-to-death physiological processes is still poor. Tree senescence, including the role of telomeres in ageing processes [17], is still not fully understood [18•].

In conclusion, although tree death processes are not yet fully understood, tree mortality rates may be used as indicators of tree vitality within a forest stand. However, although counting dead trees in a forest is certainly feasible, analysing and interpreting tree mortality rates are difficult [19-21]. Tree mortality rates in natural conditions are completely unknown, and they vary strongly depending on species and site conditions. Moreover, data about mortality rates in the past are not available and are difficult to estimate due to logging and the removal of deadwood by humans. Even in unmanaged forests, it may be difficult to determine when any dead trees actually died, making calculation of mortality rates extremely difficult. Large (50 ha), long-term monitoring plots where every tree is tagged and repeatedly assessed are beginning to shed light on this important question, and the information will steadily improve as long as the monitoring is maintained [22]. Without a comparison in space or time, tree mortality rates are difficult to interpret as indicators of forest health.

\section{Tree Physiological Processes}

Tree vitality includes the power of the tree to live and grow. Photosynthesis, which is the process by which trees synthesize carbohydrates from carbon dioxide and water using sun energy, is theoretically the most appropriate indicator of tree productivity and vitality. However, data on photosynthesis rates require precision measurements and expensive equipment that are difficult to use in the forest. As a result, photosynthesis is seldom considered in long-term forest monitoring programmes. Likewise, other indicators of tree biochemical and physiological processes, such as phytohormones or enzymes, luminescence, needle emissions, cambial electrical resistance, and electronic potential [23] cannot be considered in forest surveys because of the costs involved in their analysis and the practical difficulties encountered when trying to take measurements in the forest.

Data acquisition of physiological processes using remote sensing techniques can cost less than data acquired during ground-based fieldwork. However, fieldwork is essential for ground validation of remote sensing data and is indispensable 
when indicators cannot be observed through remote sensing technology within an acceptable range of accuracy. As a consequence, forest health assessments are commonly undertaken by relating field observations (e.g., defoliation or discoloration) to remotely sensed measures.

Remote sensing techniques for monitoring forest health include airborne imaging spectroscopy to derive vegetation indices, airborne laser scanning penetration variables, and spectral mixture analysis $[24,25]$. The most important photosynthesis indicator used in the assessment of tree vitality is chlorophyll fluorescence, which is assessed using spectrometry [26]. Chlorophyll fluorescence is useful for assessing the overall ability of trees to produce carbohydrates and has also been suggested as a way to diagnose plant stress caused by environmental factors [27]. However, this method has been more widely applied in urban tree-monitoring programmes than in forest health surveys.

In conclusion, remote sensing can be used to assess tree vitality, but the data obtained through remote sensing must be validated with ground data. It is perhaps for this reason that remote sensing has seldom been used in forest surveys to assess vitality. However, recent advances in remote sensing make the development of methods to assess photosynthetic rates easier and more promising for forest-scale studies [28].

\section{Crown Transparency}

Since the first observations of forest decline during the 1970s in Central Europe, crown foliage transparency has been commonly believed to be the best indicator of tree condition in relation to air pollution. For this reason, it has been widely adopted as the most important indicator of tree vitality. Although crown transparency assessment has been criticized vehemently because it is highly subjective and not causespecific [29], European forest health has been assessed for the past 30 years using this indicator [12]. This wealth of data has shown that most of the variability associated with crown transparency assessments is the result of methodological differences, differences in tree age, and some climatic factors, mainly drought [30], rather than air pollution [8]. Crown transparency is therefore not a good indicator of tree vitality, although it continues to be recommended as an indicator when used in association with other indices of crown condition [31-33].

\section{Tree Productivity, Biomass, and Volume}

Tree productivity is often considered to be an expression of tree vitality. However, its use is questionable because the most productive trees are not always in good health. For example, tree growth may increase as a reaction to fungal attacks or injury. Trees may also grow very slowly in the shade of other trees for hundreds of years, only becoming truly productive once they are exposed to more light. Moreover, trees may enhance their growth in response to disruptions in the forest ecosystem cycle, such as increased nitrogen availability induced by atmospheric deposition. Even if such trees are evaluated as being in good health, their growth rates are not good indicators of the overall health of the forest. Nonetheless, tree productivity is commonly used as an indicator of tree health in surveys performed throughout the world, especially within the context of production forestry.

To assess tree productivity, the carbohydrates being produced, i.e., the carbon fixed through photosynthesis, should be measured. As it is difficult to measure carbohydrate production in the field, tree biomass, as derived from tree volume, is used. Thus, tree volume is often taken as an indicator of tree vitality. However, tree volume itself is difficult to assess, as it includes foliage, branches, and roots. Indeed, the root system is thought to be of considerable volume, but is almost impossible to measure. Even if the root system were to be extracted from the soil, the volume would be underestimated, as it would exclude the fine roots, which seem to be a conspicuous part of the root system. For this reason, tree stem volume alone is used to assess tree productivity and therefore vitality.

Tree stem volume should be measured using Archimedes' principle, but because this is impractical in a forest setting, it is usually calculated from basal area and tree height. The tree taper, i.e., the degree to which a tree stem decreases in diameter as a function of height above ground, should be taken into account. In practice, stem volume is calculated from measurements of tree diameter at breast height $(1.3 \mathrm{~m}$ height $)$ and overall tree height.

A good example of assessing tree productivity, i.e., carbon (C) content, is offered by Bascietto et al. [34]. The results of their study showed that ring width and stem analyses may be used to reconstruct tree stem volume and carbon production.

Tree productivity, biomass, and volume are certainly indicators of tree growth, but they are difficult and timeconsuming to estimate, and strongly affected by errors and approximations.

\section{Basal Area Increment}

Basal area increment may be used as a proxy for volume [35]. The advantage of using basal area instead of ring width is that no data standardization is needed to remove the geometrical age trend, i.e., the decreasing trend in ring width due to the increasing stem circumference with tree age, preserving all other long-term trends [36]. To obtain accurate results, stem disks are needed because extrapolating basal area increment using tree cores often introduces mistakes that compromise the results. However, the use of stem disks requires that the tree be felled. 


\section{Tree-Ring Growth}

Given the difficulties in calculating tree stem volume, and the uncertainty of tree volume estimates, tree-ring measurements have often been preferred to stem volume assessments in forest health surveys. Particularly when assessing forest health over large areas, dendrochronological studies provide information about the growth of a large number of trees without the need to fell them. Tree-ring studies also allow for the reconstruction of past tree growth over time. Therefore, tree-ring width, as an indicator of tree volume growth, is a widely used indicator of tree vitality.

In temperate climates, the cambial activity of trees and shrubs stops during the cold season, resulting in the formation of annual growth rings. Tree rings have been used for reconstructing past climatic conditions and events. More broadly, tree rings can be used as indicators of the environmental conditions (not only climatic) in which trees have been growing because their chemical and physical characteristics depend on the environmental conditions in which they grew. Tree-ring analysis has contributed significantly to the discussion about the impact of environmental changes on tree growth and tree vitality. However, many different factors can have the same effect on tree growth, making it difficult to disentangle the effects of different factors.

In studies of the impact of air pollution on forests, dendroecological methods have been used to identify anomalous growth trends. However, unlike the effects of point sources [37], the large-scale diffuse impacts of air pollution on forests are still unclear $[4,38]$. In Central Europe, for example, abrupt growth decreases were detected during the 1980s $[39,40]$. Some pioneering studies around pollution point sources, such as smelters, have documented a decrease in tree growth as a consequence of water, air, and soil pollutants [41]. Studies of the impact of air pollution at a regional scale have been more controversial [42]. Stand dynamics seem to have strongly affected the results of many of these studies [43].

Tree-ring studies provide information about past growth rates, but the interpretation of long-term growth trends is difficult. Many dendroecological studies of long-term growth trends are affected by sampling bias because of the influence of stand dynamics (e.g., mortality, competition, disturbance). In particular, the restriction of sampling to a few of the largestdiameter trees within a stand may have a marked influence on the ensuing results [44]. When assessing long-term growth trends, most investigators sample the largest-diameter trees in a stand. This strategy has arisen from the desire to sample the oldest trees in a stand, which are often incorrectly assumed to be the largest. However, tree-ring patterns and the sizes of trees are strongly affected by forest management and natural disturbances [45]. The effects of restricting sampling to the largest trees have never been adequately documented, although recent studies have shown that different sampling strategies achieve different results [46].

The weakness of ring width as an indicator is also shown by tree-ring studies of trees grouped into vitality classes to test growth differences between the classes [47]. While many of these studies show decreased growth and higher crown transparency, others show no such relation [48], or no relationship at low to moderate levels of transparency [49]. Although it has been demonstrated that crown transparency correlates with subsequent tree mortality in some cases [50], an unambiguous relationship between crown transparency and tree growth cannot be demonstrated. Similarly, attempts to relate the results obtained from dendrometer bands to crown transparency have yielded few significant relationships.

In conclusion, tree-ring widths have frequently been used as indicators of tree vitality in forest stands suffering environmental stress. However, the majority of such studies are affected by potential sampling bias, and by uncertainty related to whether growth changes are the result of stand dynamics or an independent change in tree vitality.

\section{Tree-Ring Stable Isotopes as Integrative Physiological Indicators of Tree Vitality}

\section{Tree-Ring Stable Isotopes}

Stable isotopes are important tools for evaluating the impact of biotic (e.g., pest outbreaks and fungal diseases) and abiotic (e.g., extreme climatic events, fire, air pollution, direct damage due to management operations) factors on forest health and vitality. If the stress conditions are not so harsh as to prevent tree growth, i.e., allowing tree-ring formation, treering stable isotopes can be used to assess retrospectively the impact of environmental disturbances on tree vitality. However, it is extremely difficult to disentangle the role of the different disturbances in forest decline episodes [51, 52].

\section{Carbon Stable Isotopes}

Tree-ring carbon stable isotope ratios $\left(\delta^{13} \mathrm{C}\right)$ are powerful proxies used in climate reconstructions [53] and are increasingly used to help unravel tree physiological processes [54].

Tree-ring carbon stable isotope ratios can be considered an integrated indicator of tree vitality over time. Plants discriminate against the heavier carbon isotope ${ }^{13} \mathrm{C}$; as a result, plant material is depleted in ${ }^{13} \mathrm{C}$ relative to air $\mathrm{CO}_{2}$. A negative sign indicates that the plant sample has a lower ${ }^{13} \mathrm{C} /{ }^{12} \mathrm{C}$ ratio than the standard (PDB), and a lower discrimination is indicated by a higher, i.e., less negative, $\delta^{13} \mathrm{C}$. In $\mathrm{C}_{3}$ plants, the discrimination is driven by two fractionation processes: (a) diffusion of $\mathrm{CO}_{2}$ through stomata, reducing $\delta^{13} \mathrm{C}$ by $4.4 \%$, and (b) the enzymatic process of carboxylation, which further reduces 
$\delta^{13} \mathrm{C}$ by $27 \%$. The carbon isotope ratio $\left(\delta^{13} \mathrm{C}\right)$ is therefore affected by both changes in atmospheric $\mathrm{CO}_{2}$ concentrations $\left(c_{a}\right)$ and by changes in the substomatic chamber or intercellular $\left(\mathrm{c}_{\mathrm{i}}\right) \mathrm{CO}_{2}$ concentrations. The $\mathrm{CO}_{2}$ input rate $\left(\mathrm{g}_{\mathrm{s}}\right)$ of the substomatic chamber is regulated by the stomata; the output rate is regulated by $\mathrm{CO}_{2}$ assimilation (A). These processes are strongly influenced by environmental variables such as light, temperature, and water and nutrient availability, which are then reflected in tree-ring stable isotopes [55].

In general, ${ }^{13} \mathrm{C}$ discrimination declines under stress conditions, such as water shortage. This may be attributed to partial or complete stomatal closure in the case of water stress, which causes limited diffusion of both $\mathrm{CO}_{2}$ and $\mathrm{H}_{2} \mathrm{O}$ and thus less carbon isotope discrimination [47]. However, stomatal conductance responds not only to water availability but also to water demand. This means that other variables such as air relative humidity, vapour pressure deficit, and potential evapotranspiration also affect discrimination [56]. Furthermore, other stress conditions induced by changes in temperature, light, $\mathrm{CO}_{2}$ concentrations, or nutrient availability [57] could influence stomatal conductance and lead to increases in the $\mathrm{CO}_{2}$ assimilation rate via Rubisco. This increase leads to a corresponding decrease in $\mathrm{c}_{\mathrm{i}} / \mathrm{c}_{\mathrm{a}}$ and causes plants to discriminate less against ${ }^{13} \mathrm{C}$. Furthermore, through its relationship with the ratio between the intercellular and the atmospheric $\mathrm{CO}_{2}$ partial pressures, tree-ring $\delta^{13} \mathrm{C}$ has been widely used to study intrinsic water use efficiency in plants ( $\left.{ }_{\mathrm{i}} \mathrm{WUE}\right)[55,58]$.

In tree-ring cellulose, the $\delta^{13} \mathrm{C}$ incorporates additional sources of variation unrelated to environmental factors, such as fractionation processes taking place during the mobilization of photosynthetic assimilates from the leaf to tree-ring production [59]. For instance, the tree may use remobilized stored carbohydrates (primarily starch) for the construction of new wood cells. This is the so-called memory effect $[60,61]$. As a consequence, the tree ring might have the signal of the year in which the starch was produced, which may differ from the year in which it is incorporated into the tree ring by many months or even years [62].

\section{Oxygen Stable Isotopes}

Oxygen stable isotopes $\left(\delta^{18} \mathrm{O}\right)$ are another important source of environmental information that can be extracted from trees [63]. Tree $\delta^{18} \mathrm{O}$ includes three variable components beyond source water variability: (1) the leaf water enrichment, modified by the Péclet effect and the dampening of $\delta^{18} \mathrm{O}$ at evaporation sites due to leaf water heterogeneity, (2) the biochemical fractionation between carbonyl oxygen and water during cellulose synthesis, and (3) the $\delta^{18} \mathrm{O}$ of water vapor outside the leaf, mostly influenced by relative humidity [64]. Furthermore, tree $\delta^{18} \mathrm{O}$ can be used to discriminate between biochemical and stomatal limitations to photosynthesis, since it shares a dependence on stomatal conductance $\left(g_{s}\right)$ with plant $\delta^{13} \mathrm{C}$, but is unaffected by changes in net photosynthetic activity (A) [65].

\section{Using Carbon and Oxygen Stable Isotopes to Study Air Pollution}

Variations in atmospheric gas concentrations, such as the increases in $\mathrm{CO}_{2}$ concentrations, air pollution, and acidic precipitation due to fossil fuel combustion, affect forest ecosystems at individual tree and canopy levels. Stable isotopes have largely been applied to assess the physiological mechanisms induced by those factors and to better understand their implications for the global carbon, water, and nitrogen cycles (see Table 1 Supplementary Material). For example, in several forests, elevated $\mathrm{CO}_{2}$ concentrations, temperature, and drought increase seem to promote an increase in plant water use efficiency with an enhancement of photosynthesis and a generally modest reduction in stomatal conductance [66]. The influence of each factor is still under debate and difficult to disentangle [67]. Tree-ring $\delta^{13} \mathrm{C}$ samples from around the globe show an increase in ${ }_{i} W U E$ since pre-industrial times $[68,69]$. Exposure to $\mathrm{SO}_{2}$ and $\mathrm{O}_{3}$ has been reported to inhibit photosynthesis by inducing stomatal closure [70, 71]. Meanwhile, elevated $\mathrm{NO}_{\mathrm{x}}$ concentrations may increase photosynthetic rates by activating carboxylation enzymes due to the " $\mathrm{N}$ fertilization effect" during short-term exposure [72] or in the long-term trend [73]. However, long-term exposure is believed to cause forest decline. The general isotopic response to air pollution is a reduced discrimination against ${ }^{13} \mathrm{C}$ due to stomatal closure, which creates higher $\delta^{13} \mathrm{C}$ values in tree rings and leaf tissues. Such studies reported that the increase in $\delta^{13} \mathrm{C}$ in plant tissues is mainly due to [1] stimulated activities of PEP carboxylase, [2] change in cell metabolism, [3] decline in carboxylation efficiency due to collapse of mesophyll cells, or [4] higher rates of dark respiration, with no significant changes in the stomata aperture (Table 1 Supplementary Material). The majority of the studies around point-source pollution under real field conditions showed an increase of tree-ring $\delta^{13} \mathrm{C}$ values $[74,75]$.

\section{Using Nitrogen Stable Isotopes to Study Air Pollution}

Besides $\delta^{13} \mathrm{C}$, most of the studies on the effects of air pollution on tree growth and physiology are based on $\delta^{15} \mathrm{~N}$ that can provide indications of changes in ecosystem $\mathrm{N}$ cycling in response to the different pollution sources [76].

Studies of nitrogen stable isotopes in tree rings started some decades ago. Poulson et al. [76] measured nitrogen isotopes in two individuals of Tsuga canadensis to study the effect of atmospheric $\mathrm{N}$ deposition on a forest in $\mathrm{NH}$, USA. Both trees showed a decreasing trend in $\delta^{15} \mathrm{~N}$ from the 1960s to the 1990s and an increasing nitrogen concentration. The authors attributed this result to the increasing emission of NOx in the 
USA, which leads to increasing atmospheric deposition of isotopically light nitrate and ammonium in acid rain. The anthropogenic impact on natural nitrogen isotope variation was also studied in a polluted area of Germany by Jung et al. [77]. The authors found that Pinus sylvestris needles and tree rings were more depleted in $\delta^{15} \mathrm{~N}$ and had lower $\mathrm{N}$ concentrations at sites further from the industrial agglomeration. Ammann et al. [78] investigated $\delta^{115} \mathrm{~N}$ in Picea abies needles in a forest in the Swiss Central Plateau, near a highway. They found the highest values in plots closest to vehicular traffic and estimated that vehicular emissions contributed about $25 \%$ of the $\mathrm{N}$ nutrition of the needles. At the same site, Saurer et al. [75] studied a transect of Picea abies perpendicular to the highway, to determine the effect of NOx from car exhaust on tree growth. They found that the trees growing nearest the highway exhibited a disturbance in nitrogen concentration and a dramatic increase in tree-ring $\delta^{15} \mathrm{~N}$ signal starting when the highway was built. This study confirmed that tree rings can be an environmental monitoring tool and that the isotopic signal of $\mathrm{N}$ sources can be stored in them. However, Battipaglia et al. [79] could not find any clear $\delta^{15} \mathrm{~N}$ signal in tree rings close to a traffic pollution source, showing that radiocarbon is a much better indicator of changes in air quality due to fossil fuel combustion. Burning fossil fuel introduces $\mathrm{CO}_{2}$ that has no ${ }^{14} \mathrm{C}$ into the atmosphere, which influences the global atmospheric $\mathrm{CO}_{2^{-}}{ }^{14} \mathrm{C}$ signal, i.e., the Suess effect [80]. Several other papers have coupled $\delta^{15} \mathrm{~N}$ with $\delta^{18} \mathrm{O}$ and $\delta^{13} \mathrm{C}$ to monitor plant exposure to elevated oxidant pollutants such as ozone, sulfur dioxide, and NOx using different temporal and spatial perspectives [81]. However, both the magnitude and the direction of the reported isotope effects have varied as a result of the opposing effects of fossil fuel ${ }^{13} \mathrm{CO}_{2}$ dilution and the effects of secondary combustion products on tree physiology. Thus, it can be difficult to extract general trends from these data.

\section{Pest Outbreaks}

Few studies have examined the effects of insect outbreak events on tree-ring stable isotope composition, and the results of those that exist are rather controversial. Although it is well known that host plants can change their physiology by altering their water relations and their modifying photosynthate allocation and photosynthetic capacity as a consequence of insect defoliation, the isotope signals do not always reveal changes in discrimination rate. Leavitt and Long [82] compared treering carbon stable isotopes of two host species (Abies concolor and Pseudotsuga menziesii) during a western spruce budworm outbreak in the USA. Although they observed an increase in $\delta^{13} \mathrm{C}$ when compared to a non-host species (Pinus ponderosa), they did not record any change in discrimination in the host species due to the pest outbreak. Likewise, Ellsworth et al. [83] did not observe any variation in $\delta^{13} \mathrm{C}$ or ${ }_{i}$ WUE in the leaves remaining on deciduous trees after an infestation of piercing-sucking insects in AZ (USA). A similar lack of response was observed by Haavik et al. [84] in a study of growth patterns of Quercus rubra during and after a pest infestation in the late 1990s.

In contrast, Simard et al. [85] reported ${ }^{13} \mathrm{C}$ enrichment in Abies balsamea and Picea mariana following defoliation by the spruce budworm Choristoneura fumiferana in boreal forest of Quebec. However, they found no differences in $\delta^{18} \mathrm{O}$ values during and after the outbreak and concluded that the observed ${ }^{13} \mathrm{C}$ enrichment could be explained by both an increase in photosynthetic rate and the remobilisation of starch reserves during severe defoliation. Kress et al. [86] inferred that larch budmoth (LBM) did not impact the carbon and oxygen tree-ring isotope signatures of Larix decidua trees on European Alps. Similarly, Weidner et al. [87] observed that the loss of needles due to LBM outbreaks did not significantly influence the tree-ring carbon isotope signature. In contrast to carbon isotopes, however, they found that oxygen isotopes seemed to react much more sensitively to strong LBM infestations. This could be because during the main defoliation event, photosynthesis does not take place due to either a lack of needles or desiccated or dysfunctional (brown) needles. Accordingly, very few photosynthates are produced. They therefore suggested that tree-ring cellulose formed during LBM outbreak years is built with carbohydrates formed either before the heavy feeding occurs or shortly thereafter, i.e., when new foliage emerges 3-4 weeks after defoliation. Simard et al. [88] (2012) investigated the potential use of tree-ring isotope composition to identify different degrees of past spruce budworm defoliation episodes in seedlings of Abies balsamea grown in a controlled experiment. They reported an enrichment of ${ }^{13} \mathrm{C}$ in moderately to heavily defoliated seedlings, probably due to the remobilization of stored carbohydrates enriched in ${ }^{13} \mathrm{C}$. They did not observe any variation in carbon composition in seedlings that experienced less severe defoliation.

\section{Other Disturbances}

Natural forest disturbances, such as fires, windstorms, or flooding, are expected to increase in both severity and frequency under global warming and to seriously affect forest health and ecosystem services. Stable isotopes in tree rings have the potential to provide information about the frequency and severity of extreme events in the past, thereby aiding with extreme-hazard assessments.

To aid with the understanding of the physiological responses of trees to wildfire in southern Europe, the dual-isotope approach [89], which combines the analysis of $\delta^{13} \mathrm{C}$ and $\delta^{18} \mathrm{O}$, has been used to discriminate between biochemical and stomatal limitation to photosynthesis [90-98]. Indeed, fire can damage the crown, reducing leaf surface and altering the plant's photosynthetic rates and, being the plant $\delta^{18} \mathrm{O}$ related to 
stomatal conductance (gs) but unaffected by photosynthesis (A), it can help separate the independent effects of A and gs on $\delta^{13} \mathrm{C}$.

Other studies demonstrated physiological consequences of fire deficits in forests of the western United States [99] and in trees growing on permafrost in boreal ecosystems [100]. All of these studies demonstrated that the responses of the trees, and thus of the stable isotope signature, depend on fire severity. Severe wildfires that result in partial or complete crown defoliation lead to a simultaneous enrichment of $\delta^{13} \mathrm{C}$ and $\delta^{18} \mathrm{O}$ in tree rings. This is because trees close their stomata and decrease their photosynthetic activity $[92,98,99]$. Medium and low severity fires produce little to no change in $\delta^{13} \mathrm{C}$, no change in $\delta^{18} \mathrm{O}$, and a partial reduction in tree growth due to the lower photosynthetic capacity of the burned trees [79].

\section{Tree Response to Drought}

Over the past decades, there has been a worldwide increase in reports of drought-related forest declines $[11,101]$. The declines are seemingly triggered by multiple, interacting factors, ranging from drought to insect pests and diseases and to afforestation with poorly adapted non-native species. This makes it difficult, if not impossible, to disentangle the drivers of forest declines. Abiotic stress factors can induce forest health problems and extreme climate events, particularly drought, are thought to be a primary factor triggering many extensive forest pest outbreaks and fungal diseases [102].

There are two main physiological processes involved during tree mortality:

1. Hydraulic failure processes, induced by reduced soil water supply coupled with high evaporative demand. This causes xylem conduits and the rhizosphere to cavitate, stopping the flow of water and desiccating plant tissues $[103,104]$.

2. Carbon starvation processes, induced by stomatal closure. Although designed to prevent water loss, stomatal closure leads to a decrease in carbon uptake and photosynthetic activity, which causes the plant to starve as a result of its continued metabolic demand for carbohydrates.

Researchers have debated the roles of these two cooccurring processes. Adams et al. [105] stated that in most cases, both processes occur together, even if hydraulic failure can occur alone without any carbon starvation, whereas carbon starvation only occurs in conjunction with hydraulic failure. The majority of studies assessing hydraulic failure have looked at the percentage of loss of xylem conductivity (PLC), while carbon starvation was assessed via changes in tissue non-structural carbohydrate (NSC) concentrations [103]. Some studies of tree-ring stable isotopic composition show a strong coherence amongst species and strong correlations with climatic indices, including growing season, temperature, and drought. In particular, stable isotopic ratios can provide information about the water use efficiency, i.e., the amount of carbon assimilated as biomass per unit of water used by the tree. A growing body of evidence shows that plants can close their stomata during drought events to avoid unnecessary water loss. Consequently, stomatal conductance to $\mathrm{CO}_{2}$ decreases and Rubisco fixes a higher-than-usual proportion of ${ }^{13} \mathrm{C}$ compared to ${ }^{12} \mathrm{C}$. As a result, rings are formed in which the cellulose is enriched in the heavier isotope, which translates as less negative isotopic signatures and those large anomalies in their $\delta^{13} \mathrm{C}$ can be indicators of forest health [106-109]. Other studies of co-occurring healthy and dead trees found a lower ${ }_{i}$ WUE in dead trees, suggesting either a reduction in photosynthesis rates or, more probably, a poor regulation of stomatal conductance [110-112]. The higher ${ }_{i}$ WUE observed in surviving trees suggests higher photosynthesis rates or more conservative water use strategies during drought [111].

Stable isotopes are a key to understanding physiological processes related to tree vitality, and to understanding how forest declines are linked to drought events. A good example is given by Gessler et al. [113•], who developed a conceptual model based on tree-ring $\delta^{13} \mathrm{C}$ and $\delta^{18} \mathrm{O}$ isotopes. Their model suggests that when dead trees have long-lasting gas exchange and growth declines, in comparison with healthy trees, mortality is induced principally by carbon starvation, whereas rapid or no decline of both stomatal conductance and growth prior to death is indicative of hydraulic failure [99].

\section{Conclusions}

A clear definition of forest health is still missing and little progress had been made toward the developing the theoretical framework around the concept of forest health. This lack of definition is caused by the poor understanding of the physiological mechanisms underlying tree mortality and forest dieback episodes. To evaluate forest health, monitoring efforts have concentrated on the assessment of tree vitality, trying to estimate photosynthesis rates and productivity. In order to extend such estimates back in time, tree rings have been used as indicators of past productivity. In particular, tree-ring width measurements have been widely used to provide information about past climatic events, such as drought and frost, and trends and the response of trees to them. However, ring width patterns are prone to misinterpretation and do not provide any information about tree physiological processes other than those directly related to tree growth.

In the past two decades, it has become clear that tree mortality processes involve the storage and transport systems of water and photosynthate. Extreme drought events induce the loss of xylem hydraulic conductivity, causing tree death. Tree- 
ring stable isotopes have been increasingly used in the study of drought-induced forest decline and have proven to be useful tools for understanding physiological processes in the past. Although they have yet to be used to assess tree vitality rather than to study tree response to environmental stress, tree-ring stable isotopes integrate crown transpiration rates and photosynthesis rates. When analysed together with ring widths, treering stable isotopes may enhance our understanding of tree vitality. They are promising indicators of tree vitality and also allow for retrospective studies of tree physiological response to past abiotic and biotic disturbance events and trends.

Here, we have reviewed the existing literature on forest health and tree vitality indicators. We postulate that the forest dieback episodes that have been recently observed were induced by drought. We propose that some of the episodes of mortality and dieback observed during the 1970s and 1980s were also caused by drought. Stable isotopes, which integrate information about stomatal activity and photosynthesis, should be a much better indicator of tree vitality than more commonly used indicators, such as tree-ring width and crown transparency.

Considering the recent improvements in laboratory techniques and consequently the reduction of analytical costs, we call for the use of tree-ring stable isotopes in future longterm monitoring programmes.

Supplementary Information The online version contains supplementary material available at https://doi.org/10.1007/s40725-021-00137-8.

Acknowledgements The crisis circumstances created by the COVID19 outbreak gave to Paolo Cherubini the time and inspiration to think about the role of unconsidered communication of science through the media in creating societal insecurity and hysteria. We would like to thank Ms. Erin Gleeson of SciencEdit.CH for her help revising a previous draft of this paper.

Funding Open Access funding provided by Lib4RI - Library for the Research Institutes within the ETH Domain: Eawag, Empa, PSI \& WSL.

\section{Declarations}

Conflict of Interest Paolo Cherubini, Giovanna Battipaglia, and John L. Innes declare that they have no conflict of interest.

Human and Animal Rights and Informed Consent This article does not contain any studies with human or animal subjects performed by any of the authors.

Open Access This article is licensed under a Creative Commons Attribution 4.0 International License, which permits use, sharing, adaptation, distribution and reproduction in any medium or format, as long as you give appropriate credit to the original author(s) and the source, provide a link to the Creative Commons licence, and indicate if changes were made. The images or other third party material in this article are included in the article's Creative Commons licence, unless indicated otherwise in a credit line to the material. If material is not included in the article's Creative Commons licence and your intended use is not permitted by statutory regulation or exceeds the permitted use, you will need to obtain permission directly from the copyright holder. To view a copy of this licence, visit http://creativecommons.org/licenses/by/4.0/.

\section{References}

Papers of particular interest, published recently, have been highlighted as:

- Of importance

•- Of major importance

1. Schütt P. Der Stand unseres Wissens über eine aktuelle und gefährliche Komplexkrankheit der Weißtanne (Abies alba Mill.). Forstw Cbl. 1977;96:177-86.

2. Ulrich B, Pankrath J. Effects of accumulation of air pollutants in forest ecosystems. Dordrecht: De Reidel Publ. Company; 1983.

3. Schütt P, Cowling EB. Waldsterben, a general decline of forest in Central Europe: symptoms, development and possible causes. Plant Dis. 1985;69:548-58.

4. Kandler O, Innes JL. Air pollution and forest decline in Central Europe. Environ Pollut. 1995;90:171-80.

5. Canetti E. Masse und Macht. Hamburg, Claassen Verlag. 1960.

6. Büntgen U, Tegel W, Kaplan JO, Schaub M, Hagedorn F, Bürgi $\mathrm{M}$, et al. Placing unprecedented recent fir growth in a Europeanwide and Holocene-long context. Front Ecol Environ. 2014;12: $100-6$.

7. Sousa-Silva R, Verheyen K, Ponette Q, Bay E, Sioen G, Titeux H, et al. Tree diversity mitigates defoliation after a drought-induced tipping point. Glob Chang Biol. 2018;24:4304-15.

8. de Vries W, Dobbertin MH, Solberg S, van Dobben HF, Schaub M. Impacts of acid deposition, ozone exposure and weather conditions on forest ecosystems in Europe: an overview. Plant Soil. 2014;380:1-45.

9. Innes JL. Forest health: its assessment and status. Wallingford: CAB International; 1993.

10. Dobbertin M. Tree growth as indicator of tree vitality and of tree reaction to environmental stress: a review. Eur J For Res. 2005; 124:319-33.

11. Allen C, Macalady A, Bachelet D, McDowell N, Vennetier M, Kitzberger T, et al. A global overview of drought and heat-induced tree mortality reveals emerging climate change risks for forests. For Ecol Manag. 2010;259:660-84.

12. Ferretti M. Forest health assessment and monitoring - issues for consideration. Environ Monit Assess. 1997;48:45-72.

13. Jonard M, Logout A, Nicolas M, Dambrine E, Nys C, Ulrich E, et al. Deterioration of Norway spruce vitality despite a sharp decline in acid deposition: a long-term integrated perspective. Glob Chang Biol. 2012;18:711-25.

14. Trumbore S, Brando P, Hartmann H. Forest health and global change. Science. 2015;349:814-8.

15. Kannenberg SA, Schwalm CR, Anderegg WRL. Ghosts of the past: how drought legacy effects shape forest functioning and carbon cycling. Ecol Lett. 2020;23:891-901 The authors discussed key knowledge gaps pertaining to the causes of legacy effects, and how the various mechanisms that may contribute to these lags in drought recovery could have contrasting implications for the $\mathbf{C}$ cycle. Interesting overview about how to investigate drought recovery via experimental, observational, and modelling approaches.

16. Wang L, Cui J, Jin B, Zhao J, Xu H, Lu Z, et al. Multifeature analyses of vascular cambial cells reveal longevity mechanisms in 
old Ginkgo biloba trees. Proc Natl Acad Sci U S A. 2020;117: 2201-10.

17. Watson JM, Riha K. Telomeres, aging, and plants: from weeds to Methuselah - a mini-review. Gerontology. 2011;57:129-36.

18. Munné-Bosch S. Long-lived trees are not immortal. Trends Plant Sci. 2020;25:846-9. An interesting article about tree life and its limits. The author argues that long-living trees like Ginkgo biloba live so long because they have mechanisms to ease the wear and tear of time, but given how long these test subjects live, it is difficult to study what their ageing looks like. Trees have limits linked to physical and mechanical constraints, such as humans or all living organisms.

19. McDowell N, Pockman WT, Allen CD, Breshears DD, Cobb N, Kolb T, et al. Mechanisms of plant survival andmortality during drought: why do some plants survive while others succumb to drought? New Phytol. 2008;178:719-39.

20. McDowell NG, Fisher RA, Xu C, Domec JC, Holtta T, Mackay DS, et al. Evaluating theories of drought vegetation mortality using a multimodel-experiment framework. New Phytol. 2013;200:304-21.

21. McDowell N, Allen CD, Anderson-Teixeira K, Brando P, Brienen $\mathrm{R}$, Chambers J, et al. Drivers and mechanisms of tree mortality in moist tropical forests. New Phytol. 2018;219:851-69.

22. Losos EC, Leigh EG. Tropical forest diversity and dynamism. Findings from a large-scale plot network. Chicago: University of Chicago Press; 2004

23. Martinez-Trinidad T, Watson WT, Arnold MA, Lombardini L, Appel DN. Comparing various techniques to measure tree vitality of live oaks. Urban For Urban Green. 2010;9:199-203.

24. Kayet N, Pathak K, Chakrabarty A, Singh CP, Chowdary VM, Kumar S, et al. Forest health assessment for geo-environmental planning and management in hilltop mining areas using Hyperion and Landsat data. Ecol Indic. 2019;106:105471.

25. Ahmad S, Pandey AC, Kumar A, Lele NV, Bhattacharya BK. Forest health estimation in Sholayar Reserve Forest, Kerala using AVIRIS-NG hyperspectral data. Spat Inf Res. 2020;28:25-38.

26. Maxwell K, Johnson JN. Chlorophyll fluorescence- a practical guide. J Exp Bot. 2000;51:659-68.

27. Percival G. The use of chlorophyll fluorescence to identify chemical and environmental stress in leaf tissue of three oak (Quercus) species. J Arboric. 2005;31:215-27.

28. Guimaraes N, Padua L, Marques P, Silva N, Peres, Sousa JJ. Forestry remote sensing from unmanned aerial vehicles: a review focusing on the data, processes and potentialities. Remote Sens. 2020;12:1046.

29. Innes JL. Forest health surveys - a critique. Environ Pollut. 1988;54:1-15.

30. Walthert L, Ganthaler A, Mayr S, Saurer M, Waldner P, Walser $\mathrm{M}$, et al. From the comfort zone to crown dieback: Sequence of physiological stress tresholds in mature European beech trees across progressive drought. Sci Total Environ. 2021;753:141792.

31. Pollastrini M, Feducci M, Bonal D, Fotelli M, Gessler A, Grossiord G, et al. Physiological significance of forest tree defoliation: results from a survey in a mixed forest in Tuscany (central Italy). For Ecol Manag. 2016;361:170-8.

32. Gottardini E, Cristofolini F, Cristofori A, Pollastrini M, Camin F, Ferretti M. A multi-proxy approach reveals common and speciesspecific features associated with tree defoliation in broadleaved species. For Ecol Manag. 2020;467:118151.

33. Rohner B, Kumar S, Liechti K, Gessler A, Ferretti M. Tree vitality indicators revealed a rapid response of beech forests to the 2018 drought. Ecol Indic. 2021;120:106903.

34. Bascietto M, Cherubini P, Scarascia-Mugnozza G. Tree rings from a European beech forest chronosequence are useful for detecting growth trends and carbon sequestration. Can J For Res. 2004;34:481-92.
35. Biondi F. Comparing tree-ring chronologies and repeated timber inventories as forest monitoring tools. Ecol Appl. 1999;9:216-27.

36. Tognetti R, Cherubini P, Innes JL. Comparative stem-growth rates of Mediterranean trees under background and naturally enhanced ambient CO2 concentrations. New Phytol. 2000;146:59-74.

37. Nöj P, Mikkola K, Saranpää P. History of forest damage in Monchegorsk, Kola; a retrospective analysis based on tre rings. Can J For Res. 1996;26:1805-12.

38. Skelly JM, Innes JL. Waldsterben in the forests of Central Europe and Eastern North America: Fantasy or reality? Plant Dis. 1994;78:1021-31.

39. Schweingruber FH, Kontic R, Winkler-Seifert A. Eine jahrringanalytische Studie zum Nadelbaumsterben in der Schweiz. EAFV Berichte (Birmensdorf, Switzerland). 1983;253:1-29.

40. Eckstein D, Krause C, Bauch J. Dendroecological investigation of spruce trees (Picea abies (L.) Karst.) of different damage and canopy classes. Holzforschung. 1989;43:411-7.

41. Vins B. Störungen der Jahrringbildung durch Rauchschäden. Naturwissenschaften. 1961;448:484-5.

42. Innes JL, Cook ER. Tree-ring analysis as an aid to evaluating the effects of pollution on tree growth. Can J For Res. 1989;19: 1174-89.

43. Hornbeck JW, Smith RB, Federer CA. Growth decline in red spruce and balsam fir relative to natural processes. Water Air Soil Pollut. 1986;31:425-30.

44. Cherubini P, Dobbertin M, Innes JL. Potential sampling bias in long-term forest growth trends reconstructed from tree rings: a case study from the Italian Alps. For Ecol Manag. 1998;109: 103-18.

45. Innes JL, Neumann H. Past growth variations in Picea sitchensis with differing crown densities. Scand J For Res. 1991;6:395-405.

46. Nehrbass-Ahles C, Babst F, Klesse S, Nötzli M, Bouriaud O, Neukom R, et al. The influence of sampling design on tree-ringbased quantification of forest growth. Glob Chang Biol. 2014;20: 2867-85.

47. Becker M, Bräker OU, Kenk G, Schneider O, Schweingruber FH. Kronenzustand und Wachstum von Waldbäumen im Dreiländereck Deutschland-Frankreich-Schweiz in den letzten Jahrenzehnten. Allg Forstz. 1990;45:263-74.

48. Lorenz M, Eckstein D. Wachstumsreaktionen von Einzelbäumen in Douglasien-, Fichten- und Kiefernbeständen in norddeutschen Waldschadensgebieten. Forst-Holz. 1988;43:8-12.

49. Tallieu C, Badeau V, Allard D, Nageleisen LM, Breda N. Year-toyear crown condition poorly contributes to ring width variations of beech trees in French ICP level I network. For Ecol Manag. 2020;465:118071.

50. Dobbertin M, Brang P. Crown defoliation improves tree mortality models. For Ecol Manag. 2001;141:271-84.

51. McCarroll D, Loader NJ. Stable isotopes in tree rings. Quat Sci Rev. 2004;23:771-801.

52. Dawson TE, Mambelli S, Plamboek AH, Templer PH, Tu KP. Stable isotopes in plant ecology. Annu Rev Ecol Syst. 2002;33: 507-59.

53. Belmecheri $\mathrm{S}$, Lavergne A. Compiled records of atmospheric $\mathrm{CO}_{2}$ concentrations and stable carbon isotopes to reconstruct climate and derive plant ecophysiological indices from tree rings. Dendrochronologia. 2020;63:125748.

54. Shestakova TA, Martinez-Sancho E. Stories hidden in tree rings: A review on the application of stable carbon isotopes to dendrosciences. Dendrochronologia. 2020;65:125789.

55. Farquhar G, Ehleringer J, Hubick KT. Carbon isotope discrimination and photosynthesis. Annu Rev Plant Physiol Plant Mol Biol. 1989;40:503-37. 
56. Ferrio JP, Voltas J. Carbon and oxygen isotopes ratio in wood constituents of Pinus halepensis and indicator of precipitation, temperature and vapour pressure deficit. Tellus. 2005;57:164-73.

57. Schulze ED, Nicolle D, Boerner A, Lauerer M, Aes G, Schulze I. Stable carbon and nitrogen isotope ratios of Eucalyptus and Acacia species along a seasonal rainfall gradient in Western Australia. Trees. 2014;28:1125-35.

58. Adams MA, Buckley TN, Turnbull TL. Diminishing CO2-driven gains in water-use-efficiency of global forests. Nat Clim Chang. 2020;10:466-71.

59. Gessler A, Ferrio JP, Hommel R, Treydte K, Werner RA, Monson RK. Stable isotopes in tree rings: towards a mechanistic understanding of isotope fractionation and mixing processes from the leaves to the wood. Tree Physiol. 2014;34:796-818.

60. Richardson AD, Carbone MS, Keenan TF, Czimczik CI, Hollinger DY, Murakami P, et al. 2013. Seasonal dynamics and age of stemwood nonstructural carbohydrates in temperate forest trees. New Phytol. 2013;197:850-61.

61. McCarroll D, Whitney M, Young GHF, Loader NJ, Gagen MH. A simple stable carbon isotope method for investigating changes in the use of recent versus old carbon in oak. Tree Physiol. 2017;37: 1021-7.

62. Barbour M. Stable oxygen isotope composition of plant tissue: a review. Funct Plant Biol. 2007;34:83-94. https://doi.org/10.1071/ FP06228.

63. Roden JS, Ehleringer JR. Hydrogen and oxygen isotope ratios of leaf water and tree-ring cellulose for field grown riparian trees. Oecologia. 2000;123:481-9.

64. Scheidegger Y, Saurer M, Bahn M, Siegwolf R. Linking stable oxygen and carbon isotopes with stomatal conductance and photosynthetic capacity: a conceptual model. Oecologia. 2000;125: 350-7.

65. Battipaglia G, Saurer M, Cherubini P, Calfapietra C, McCarthy $\mathrm{HR}$, Norby RJ, et al. Elevated $\mathrm{CO} 2$ increases tree-level intrinsic water use efficiency: insights from carbon and oxygen isotope analyses in tree rings across three forest FACE sites. New Phytol. 2013;197:544-54.

66. Saurer M, Siegwolf RTW, Schweingruber FH. Carbon isotope discrimination indicates improving water-use efficiency of trees in northern Eurasia over the last 100 years. Glob Chang Biol. 2004;10:2109-20.

67. Walker AP, De Kauwe MG, Bastos A, Belmecheri S, Georgiou K, Keeling R, et al. Integrating the evidence for a terrestrial carbon sink caused by increasing atmospheric $\mathrm{CO}_{2}$. New Phytol. 2021;229:2413-2445. https://doi.org/10.1111/nph.16866.

68. Guerrieri R, Belmecheri S, Ollinger SV, Asbjornsen H, Katie Jennings K, Xiao J, et al. Disentangling the role of photosynthesis and stomatal conductance on rising forest water-use efficiency. Proc Natl Acad Sci U S A. 2019;116:16909-14.

69. Novak K, Cherubini P, Saurer M, Fuhrer J, Skelly JM, Kräuchi N, et al. Ozone air pollution effects on tree-ring growth, $\delta^{13} \mathrm{C}$, visible foliar injury and leaf gas exchange in three ozone-sensitive woody plant species. Tree Physiol. 2007;27:941-9.

70. Pollastrini M, Desotgiu R, Cascio C, Bussotti F, Cherubini P, Saurer M, et al. Growth and physiological response to ozone and mild drought stress of tree species with different ecological requirements. Trees. 2010;24:695-704.

71. Siegwolf R, Matyssek R, Saurer M, Maurer S, Günthardt-Goerg MS, Schmutz P, et al. Stable isotope analysis reveals differential effects of soil nitrogen and nitrogen dioxide on the water use efficiency in hybrid poplar leaves. New Phytol. 2011;149:233-46.

72. Guerrieri R, Mencuccini M, Sheppard L, Saurer M, Perks M, Levy $\mathrm{P}$, et al. The legacy of enhanced $\mathrm{N}$ and $\mathrm{S}$ deposition as revealed by the combined analysis of $\delta 13 \mathrm{C}, \delta 18 \mathrm{O}$ and $\delta 15 \mathrm{~N}$ in tree rings. Glob Chang Biol. 2011;17:1946-62.
73. Freyer HD. On the $13 \mathrm{C}$ record in tree rings. Part II. Registration of microenvironmental $\mathrm{CO} 2$ and anomalous pollution effect. Tellus. 1979;31:308-12.

74. Savard MM, Bégin C, Parent M, Smirnoff A, Marion J. The environmental impact of smelter $\mathrm{SO} 2$ emissions - a time and space perspective recorded by carbon isotope ratios in tree ring cellulose. J Environ Qual. 2004;33:13-26.

75. Saurer M, Cherubini P, Ammann M, De Cinti B, Siegwolf R. First detection of nitrogen from NOx in tree rings: $a^{15} \mathrm{~N} /{ }^{14} \mathrm{~N}$ study near a motorway. Atmos Environ. 2004;38:2779-87.

76. Poulson SR, Chamberlain CP, Friedland AJ. Nitrogen isotope variation of tree rings as a potential indicator of environmental change. Chem Geol. 1995;125:307-15.

77. Jung K, Gebauer G, Gehre M, Hoffmann D, Weissflog L, Schürmann G. Anthropogenic impacts on natural nitrogen isotope variations in Pinus sylvestris stands in an industrially polluted area. Environ Pollut. 1997;97:175-81.

78. Ammann M, Siegwolf RTW, Pichelmayer F, Suter M, Saurer M, Brunold C. Estimating the uptake of traffic derived NO2 from $15 \mathrm{~N}$ abundance in needles of Norway spruce. Oecologia. 1999;118:124-31.

79. Battipaglia G, Marzaioli F, Lubritto C, Altieri S, Strumia S, Cherubini $\mathrm{P}$, et al. Traffic pollution affects tree-ring width and isotopic composition of Pinus pinea. Sci Total Environ. 2010;408:586-93.

80. Capano M, Marzaioli F, Sirignano C, Altieri S, Lubritto C, D'Onofrio A, et al. 14C AMS measurements in tree rings to estimate local fossil CO2 in Bosco Fontana forest (Mantova, Italy). Nucl Instrum Methods Phys Res, Sect B. 2010;268:1113-6.

81. Savard M. Tree-ring stable isotopes and historical perspectives on pollution - an overview. Environ Pollut. 2010;158:2007-13.

82. Leavitt SW, Long A. Influence of site disturbance on $813 \mathrm{C}$ isotopic time series from tree rings. In: In: Proceedings of the International Symposium of Ecological Aspects of Tree-Ring Analysis, 17-21 August. Tarrytown: US Department of Energy/US Environmental Protection Agency/US Department of Agriculture; 1986. p. 119-29.

83. Ellsworth DS, Tyree MT, Parker BL, Skinner M. Photosynthesis and water-use efficiency of sugar maple (Acer saccharum) in relation to pear thrips defoliation. Tree Physiol. 1994;14:619-32.

84. Haavik LJ, Stephen FM, Fierke MK, Salisbury VB, Leavitt SW, Billings SA. Dendrochronological parameters of northern red oak (Quercus rubra L. (Fagaceae)) infested with red oak borer (Enaphalodes rufulus (Haldeman) (Coleoptera: Cerambycidae)). For Ecol Manag. 2008;255:1501-9.

85. Simard S, Elhani S, Morin H, Krause C, Cherubini P. Carbon and oxygen stable isotopes from tree-rings to identify spruce budworm outbreaks in the boreal forest of Quebec. Chem Geol. 2008;252:80-7.

86. Kress A, Young GHF, Saurer M, Loader NJ, Siegwolf RTW, McCarroll D. Stable isotope coherence in the earlywood and latewood of tree-line conifers. Chem Geol. 2009;268:52-7.

87. Weidner K, Heinrich I, Helle G, Löffler J, Neuwirth B, Schleser G, et al. Consequences of larch budmoth outbreaks on the climatic significance of ring width and stable isotopes of larch. Trees. 2010;24:399-409.

88. Simard SW, Beiler KJ, Bingham MA, Deslippe JR, Philip LJ, Teste FP. Mycorrhizal networks: mechanisms, ecology and modelling. Fungal Biol Rev. 2012;26:39-60.

89. Roden JS, Farquhar GD. A controlled test of the dual-isotope approach for the interpretation of stable carbon and oxygen isotope ratio variation in tree rings. Tree Physiol. 2012;32:490-503.

90. Beghin R, Cherubini P, Battipaglia G, Siegwolf R, Saurer M, Bovio G. Tree-ring growth and stable isotopes (13C and $15 \mathrm{~N})$ detect effects of wildfires on tree physiological processes in Pinus sylvestris L. Trees. 2011;25:627-36. 
91. Battipaglia G, De Micco V, Fournier T, Aronne G, Carcaillet C. Isotopic and anatomical signals for interpreting fire-related responses in Pinus halepensis. Trees. 2014;28:1095-104.

92. Battipaglia G, Strumia S, Esposito A, Giuditta E, Sirignano C, Altieri S, et al. The effects of prescribed burning on Pinus halepensis Mill. as revealed by dendrochronological and isotopic analyses. For Ecol Manag. 2014;334:201-8.

93. Battipaglia G, Savi T, Ascoli D, Castagneri D, Esposito A, Mayr $\mathrm{S}$, et al. Effects of prescribed burning on ecophysiological, anatomical and stem hydraulic properties in Pinus pinea L. Tree Physiol. 2016;36:1-13.

94. De Micco V, Balzano A, Zalloni E, Battipaglia G. Fire influence on Pinus halepensis: wood responses close and far from the scars. IAWA J. 2013;34:446-58.

95. Alfaro-Sánchez R, Camarero J, Sánchez-Salguero R. Post- fire Aleppo pine growth, $\mathrm{C}$ and $\mathrm{N}$ isotope composition depend on site dryness. Trees. 2016;30:581-95.

96. Valor T, Casals P, Altieri S, González-Olabarria JR, Piqué M, Battipaglia G. Disentangling the effects of crown scorch and competition release on the physiological and growth response of Pinus halepensis Mill. using $\delta 13 \mathrm{C}$ and $\delta 18 \mathrm{O}$ isotopes. For Ecol Manag. 2018;424:276-87.

97. Valor T, Battipaglia G, Piqué M, Altieri S, González-Olabarria JR, Casals P. The effect of prescribed burning on the drought resilience of Pinus nigra ssp. salzmannii Dunal (Franco) and P. sylvestris L. Ann For Sci. 2020;77:13.

98. Niccoli F, Esposito A, Altieri S, Battipaglia G. Fire severity influences ecophysiological responses of Pinus pinaster Ait. Front Plant Sci. 2019;10:539.

99. Voelker SL, Merschel AG, Meinzer FC, Ulrich DEM, Spies TA, Still CJ. Fire deficits have increased drought sensitivity in dry conifer forests: fire frequency and tree-ring carbon isotope evidence from Central Oregon. Glob Chang Biol. 2019;25:1247-62.

100. Kirdyanov AV, Saurer M, Siegwolf R, Knorre AA, Prokushkin $\mathrm{AS}$, Churakova OV, et al. Long-term ecological consequences of forest fires in the continuous permafrost zone of Siberia. Environ Res Lett. 2020;15:034061.

101. Brodribb TJ, Powers J, Cochard H, Choat B. Hanging by a thread? Forest and drought. Science. 2020;368:261-6.

102. Desprez-Loustau ML, Aguayo J, Dutech C, Hayden KJ, Husson C, Jakushkin B, et al. An evolutionary ecology perspective to address forest pathology challenges of today and tomorrow. Ann For Sci. 2016;73:45-67.

103. Sevanto S, McDowell NG, Dickman LT, Pangle R, Pockman WT. How do trees die? A test of the hydraulic failure and carbon starvation hypotheses. Plant Cell Environ. 2014;37:153-61.
104. Salmon Y, Torres-Ruiz JM, Poyatos R, Martinez-Vilalta J, Meir P, Cochard $\mathrm{H}$, et al. Balancing the risks of hydraulic failure and carbon starvation: a twig scale analysis in declining Scots pine. Plant Cell Environ. 2015;38:2575-88.

105. Adams H, Zeppel M, Anderegg W, Hartmann H, Landhäusser S, Tissue D, et al. A multi-species synthesis of physiological mechanisms in drought-induced tree mortality. Nat Ecol Evol. 2017;1: 1285-91.

106. Csank AZ, Miller AE, Sherriff RL, Berg EE, Welker JM. Treering isotopes reveal drought sensitivity in trees killed by spruce beetle outbreaks in south-central Alaska. Ecol Appl. 2016;26: 2001-20.

107. Pacheco A, Camarero JJ, Pompa-García M, Battipaglia G, Voltas J, Carrer M. Growth wood anatomy and stable isotopes show species-specific couplings in three Mexican conifers inhabiting drought-prone areas. Sci Total Environ. 2020;698:134055.

108. Palandrani C, Battipaglia G, Alberti G. Influence of tree species richness on tree growth and intrinsic water-use efficiency after drought in tree plantations in north-eastern Italy. Eur J For Res. 2020;139:869-77. https://doi.org/10.1007/s10342-020-01291-7.

109. Voltas J, Aguilera M, Gutiérrez E, Shestakova TA. Shared drought responses among conifer species in the middle Siberian taiga are uncoupled from their contrasting water-use efficiency trajectories. Sci Total Environ. 2010;720:137590.

110. Colangelo M, Camarero JJ, Borghetti M, Gazol A, Gentilesca T, Ripullone F. Size matters a lot: drought-affected Italian oaks are smaller and show lower growth prior to tree death. Front Plant Sci. 2017;8:135.

111. Petrucco L, Nardini A, von Arx G, Saurer M, Cherubini P. Isotope signals and anatomical features in tree rings suggest a role for hydraulic strategies in diffuse drought-induced die-back of Pinus nigra. Tree Physiol. 2017;37:523-35.

112. Timofeeva G, Treydte K, Bugmann H, Rigling A, Schaub M, Siegwolf R, et al. Long-term effects of drought on tree-ring growth and carbon isotope variability in Scots pine in a dry environment. Tree Physiol. 2017;37:1028-41.

113. Gessler A, Cailleret M, Joseph J, Schönbeck L, Schaub M, Lehmann M, et al. Drought induced tree mortality - a tree-ring isotope based conceptual model to assess mechanisms and predispositions. New Phytol. 2018;219:485-90 Stable isotopes were indicated as a useful tool to assess drought mortality in plants. An interesting conceptual model that needs to be verified with real data.

Publisher's Note Springer Nature remains neutral with regard to jurisdictional claims in published maps and institutional affiliations. 